\title{
Respiratory System Findings Data Collection Date Time
}

National Cancer Institute

\section{Source}

National Cancer Institute. Respiratory System Findings Data Collection Date Time. NCI

Thesaurus. Code C123948.

The date and time of respiratory system data collection. 